\title{
In-Doped ZnO Hexagonal Stepped Nanorods and Nanodisks as Potential Scaffold for Highly-Sensitive Phenyl Hydrazine Chemical Sensors
}

\author{
Ahmad Umar 1,2, , Sang Hoon Kim ${ }^{1,2}$, Rajesh Kumar ${ }^{3}$, Mohammad S. Al-Assiri ${ }^{2,4}$, \\ A. E. Al-Salami ${ }^{5}$, Ahmed A. Ibrahim ${ }^{1,2,6}$ and Sotirios Baskoutas ${ }^{6, *}$ \\ 1 Department of Chemistry, Faculty of Science and Arts, Najran University, P.O. Box 1988, Najran 11001, \\ Saudi Arabia; semikim77@gmail.com (S.H.K.); ahmedragal@yahoo.com (A.A.I.) \\ 2 Promising Centre for Sensors and Electronic Devices (PCSED), Najran University, P.O. Box-1988, \\ Najran 11001, Saudi Arabia; msassiri@gmail.com \\ 3 PG Department of Chemistry, JCDAV College, Dasuya 144205, India; rk.ash2k7@gmail.com \\ 4 Department of Physics, Faculty of Science and Arts, Najran University, P.O. Box 1988, Najran 11001, \\ Saudi Arabia \\ 5 Department of Physics, Faculty of Science, King Khalid University, P.O. Box-9004, Abha 61413, \\ Saudi Arabia; Salami11@gmail.com \\ 6 Department of Materials Science, University of Patras, 26504 Patras, Greece \\ * Correspondence: ahmadumar786@gmail.com (A.U.); bask@upatras.gr (S.B.); \\ Tel.: +966-534574597 (A.U.); +30-2610969349 (S.B.)
}

Received: 26 October 2017; Accepted: 18 November 2017; Published: 21 November 2017

\begin{abstract}
Herein, we report the growth of In-doped $\mathrm{ZnO}$ (IZO) nanomaterials, i.e., stepped hexagonal nanorods and nanodisks by the thermal evaporation process using metallic zinc and indium powders in the presence of oxygen. The as-grown IZO nanomaterials were investigated by several techniques in order to examine their morphological, structural, compositional and optical properties. The detailed investigations confirmed that the grown nanomaterials, i.e., nanorods and nanodisks possess well-crystallinity with wurtzite hexagonal phase and grown in high density. The room-temperature PL spectra exhibited a suppressed UV emissions with strong green emissions for both In-doped ZnO nanomaterials, i.e., nanorods and nanodisks. From an application point of view, the grown IZO nanomaterials were used as a potential scaffold to fabricate sensitive phenyl hydrazine chemical sensors based on the I-V technique. The observed sensitivities of the fabricated sensors based on IZO nanorods and nanodisks were $70.43 \mu \mathrm{A} \cdot \mathrm{mM}^{-1} \cdot \mathrm{cm}^{-2}$ and $130.18 \mu \mathrm{A} \cdot \mathrm{mM}^{-1} \cdot \mathrm{cm}^{-2}$, respectively. For both the fabricated sensors, the experimental detection limit was $0.5 \mu \mathrm{M}$, while the linear range was $0.5 \mu \mathrm{M}-5.0 \mathrm{mM}$. The observed results revealed that the simply grown IZO nanomaterials could efficiently be used to fabricate highly sensitive chemical sensors.
\end{abstract}

Keywords: In-doped ZnO; stacked nanorods; flower-shaped; sensing; phenyl hydrazine

\section{Introduction}

Phenyl hydrazine is used for the synthesis of agricultural pesticides and insecticides, in pharmaceutical industries, rocket propellant, and explosives. Even a very low concentration of it may prove very fatal and produces drastic environmental and health hazards. The exposure of phenyl hydrazine may lead to dermatitis, skin irritation, liver and kidney damage, and hemolytic anemia [1]. According to World Health Organization and Environmental Protection Agency, phenyl hydrazine is carcinogenic and has been classified as group B2 human carcinogen [2]. Thus, a fast, reliable, highly sensitive, and selective analytical method is desired to detect even traces of phenyl hydrazine. 
Modifications of the structural, morphological, optical, chemical, electronic, and physicochemical properties of the $\mathrm{ZnO}$ semiconductor nanomaterials either through doping or through the formation of composites have always attracted the researcher to synthesize such materials [3-9]. Various doped $\mathrm{ZnO}$ nanomaterials have been recently synthesized and explored for their photocatalytic [10-12], gas sensing [13,14], photonic crystals [15], spintronics [16], electrochemical sensing [17-19], optoelectronics [20,21], dye-sensitized solar cells [22], light emitting diodes [23], field emission transistors [24,25], and many more applications. Methods like sol-gel [24,26], hydrothermal [18,27], ceramics vapor deposition [28], spin coating [29], solution combustion [30], RF sputtering [31], pulse laser deposition [32,33], etc. are reported for the synthesis of doped $\mathrm{ZnO}$ nanostructures. However, through the thermal evaporation technique, the directional growth of the nanostructures can be easily controlled by controlling the temperature and source material in contrast with the solution method in which the growth of nanomaterials are depends upon the $\mathrm{pH}$, concentration of the source materials, growth time, template/capping agent/directing agents, etc. Moreover, the use of pure metals as source material grows the nanostructures of high purity and crystallinity.

$\mathrm{ZnO}$ is an II-VI, n-type semiconductor with a wide direct band gap of $\sim 3.27 \mathrm{eV}$, large exciton binding energy $(\sim 60 \mathrm{meV})$, and high electron mobility of $115-155 \mathrm{~cm}^{2} \cdot \mathrm{V}^{-1} \cdot \mathrm{s}^{-1}$ at room temperature [34-36]. Doping with higher valence impurities, such as $\operatorname{In}^{3+}$, further enhances the conductivity $[37,38]$. It has been reported that both the conduction band, as well as the valence band energies of the $\mathrm{ZnO}$, are shifted to lower energy levels while there is no appreciable change in the band gap energy [39]. Additionally, as the ionic radius of $\operatorname{In}^{3+}(0.094 \mathrm{~nm})$ is greater than that of $\mathrm{Zn}^{2+}$ ions $(0.074 \mathrm{~nm})$, the incorporation of the $\mathrm{In}^{3+}$ ions into the $\mathrm{ZnO}$ crystal lattice further produces tensile strains leading to higher surface defects [40]. These properties make In-doped $\mathrm{ZnO}$ nanostructures suitable candidates for the fabrication of electrode for the gas, electrochemical sensing, and solar cell applications.

Chava et al. [35] synthesized In-doped $\mathrm{ZnO}$ nanoparticles through a cost-effective, low-temperature aqueous solution method, and explored them for the fabrication of photoanode in dye-sensitized solar cells. In-doped $\mathrm{ZnO}$, photoanode exhibited a high short-circuit photocurrent density of $12.58 \mathrm{~mA} / \mathrm{cm}^{2}$ and a power conversion efficiency of $2.7 \%$ as compared to the current density of $8.02 \mathrm{~mA} / \mathrm{cm}^{2}$ with $1.8 \%$ efficiency for the bare $\mathrm{ZnO}$ nanoparticles. Badadhe et al. [41] observed a very high gas response and short response and recovery times of 13,000, 2 s and $\sim 4$ min, respectively, for $1000 \mathrm{ppm} \mathrm{H}_{2} \mathrm{~S}$ at $250{ }^{\circ} \mathrm{C}$ through 3 at. \%. In-doped $\mathrm{ZnO}$ thin films deposited onto pre-cleaned glass substrates through a conventional spray pyrolysis technique. However, for $50 \mathrm{ppm} \mathrm{CO}$ gas, 1 at. \% and 2 at. \% In-doped $\mathrm{ZnO}$ nanostructures prepared by Dhahri et al. [42] showed an excellent gas response with short response and recovery times as compared to pure $\mathrm{ZnO}$ at $300{ }^{\circ} \mathrm{C}$. Wang et al. [43] explored the ethanol gas sensing applications of In-doped three-dimensionally ordered macroporous (3DOM) $\mathrm{ZnO}$ structures synthesized via a colloidal crystal templating method. High selectivity and sensitivity of the 5 at. \% In-doped $\mathrm{ZnO}$ structures as compared to pure 3DOM $\mathrm{ZnO}$ was attributed to the increased surface area, the increased electron carrier concentration due to the replacement of the $\mathrm{Zn}^{2+}$ ions from the crystal lattice by $\mathrm{In}^{3+}$ ions, along with the higher rate of $\mathrm{O}_{2}$ adsorption. Ge et al. [44] observed significant responses towards trace of various nitro-explosive vapors, including trinitrotoluene (TNT), dinitrotoluene (DNT), para-nitrotoluene (PNT), picric acid (PA), and Research Department Explosive (RDX). At room temperature using 5\% In-doped $\mathrm{ZnO}$ nanoparticles based gas sensors. The use of metal oxide nanomaterials modified electrodes, through electrochemical sensing analysis, is preferred over other traditional methods due to the excellent reliability, high sensitivity, and short response and recovery times [45].

In this paper, a facile thermal evaporation method is reported for the growth of In-doped $\mathrm{ZnO}$ (IZO) with two distinct morphologies as a function of reaction conditions on a silicon substrate. The grown nanomaterials were characterized for their morphological, structural, optical, and crystal properties through relevant characterization techniques. Further, the grown IZO nanomaterials were utilized as efficient electron mediators for the fabrication of phenyl hydrazine chemical sensor. Finally, 
a comparison was made between the In-doped $\mathrm{ZnO}$ nanorods and nanodisks for the electrochemical sensing properties towards phenyl hydrazine.

\section{Experimental Details}

\subsection{Growth of In-Doped ZnO Nanostructures}

The stepped hexagonal nanorods and disk-shaped IZO nanomaterials were grown on silicon substrate by thermal evaporation of metallic zinc ( $\mathrm{Zn}$ ) and indium (In) powders in the presence of oxygen. For the growth of stepped hexagonal nanorods, metallic $\mathrm{Zn}$ and In powders were mixed well in the ratio of 5:2, while for the disk-shaped structures, the $\mathrm{Zn}$ and In powders were mixed in the ratio of 10:3. Both of the mixtures were separately transferred to the ceramic boats and were placed at the center of the high-temperature ceramic tube furnace. Two different experiments were performed for the growth of stepped hexagonal nanorods and disk-shaped structures. Prior to the experiments, the $\mathrm{Si}(100)$ substrates were cleaned with $\mathrm{DI}$ water, ethanol, and acetone, sequentially and were dried by nitrogen gas. For both of the experiments, several pieces of $\operatorname{Si}(100)$ were placed adjacent to the source boat and ceramic tube furnace chamber was down to 1 torr using a rotary vacuum pump. For the nanorods growth, the reaction was done at $700{ }^{\circ} \mathrm{C}$, while disks were grown at $850{ }^{\circ} \mathrm{C}$ under the continuous flow of high purity nitrogen and oxygen gases with the flow-rates of 40 and $100 \mathrm{sccm}$, respectively. The reaction was terminated in 1.5-2.5 h. After completing the reaction for the desired time, the furnace was allowed to cool to room temperature and the deposited materials were characterized in terms of their morphological, structural, and optical properties.

\subsection{Characterization Techniques}

The necessary characterization techniques were utilized for the evaluation of the morphological, structural, optical, compositional, and crystal phases of the as-synthesized IZO nanostructures. Field emission scanning electron microscopy (FESEM; JEOL-JSM-7600F, JEOL, Tokyo, Japan) attached with energy dispersive spectroscopy (EDS) explored the morphological, structural, and compositional characteristics. In-doped $\mathrm{ZnO}$ nanostructures were subjected to X-ray diffraction (XRD; JDX-8030W, JEOL, Tokyo, Japan) analysis using $\mathrm{Cu}-\mathrm{K} \alpha$ radiation $(\lambda=1.54 \AA)$ in the diffraction angle range of $20-65^{\circ}$ elaborated the crystal structure, purity, crystal sizes and crystallinity. The optical properties of the deposited materials were examined by room-temperature photoluminescence (PL), measured with the He-Cd $(325 \mathrm{~nm})$ laser lines as the exciton source.

\subsection{Fabrication of Phenyl Hydrazine Electrochemical Sensor Based on IZO Nanomaterials}

To fabricate the phenyl hydrazine chemical sensors, firstly, the grown IZO nanomaterials were transferred from the substrates to the glassy carbon electrodes (GCE) and wetted by phosphate buffer solution (0.1 M PBS) with $\mathrm{pH}=7.4$ and dried gently with the flow of high purity nitrogen gas.

The PBS $(0.1 \mathrm{M}, \mathrm{pH}=7.4)$ solution was prepared by mixing $0.2 \mathrm{M}$ disodium phosphate $\left(\mathrm{Na}_{2} \mathrm{HPO}_{4}\right)$ and $0.2 \mathrm{M}$ monosodium phosphate $\left(\mathrm{NaH}_{2} \mathrm{PO}_{4}\right)$ solution in $100 \mathrm{~mL}$ de-ionized water. Consequently, 5 weight \% Nafion solution was dropped onto the modified electrode to form a net-like structure on the electrode, which can hold the functional materials during the sensing measurements. Prior to the experiments, the GCE was polished with alumina slurry and was then sonicated in de-ionized water. The modified electrode, i.e., nafion/In-doped $\mathrm{ZnO} / \mathrm{GCE}$ was finally dried at $40{ }^{\circ} \mathrm{C}$ for $12 \mathrm{~h}$. All of the electrochemical experiments were performed at room temperature by Keithley 6517A-USA (Tektronix, OR, USA) electrometer with computer interfacing with a simple current-voltage (I-V) technique. For the two electrode system, the modified electrodes were used as working electrode, in which the $\mathrm{Pt}$ wire was employed as a counter electrode. The sensitivity of the fabricated sensors was determined by plotting a calibration curve of current vs. concentration. 


\section{Results and Discussion}

\subsection{Characterization of IZO Nanostructures}

The crystallinity and crystal properties of as-grown IZO nanomaterials were examined by X-ray diffraction and the observed results are shown in Figure 1. It was observed that the stepped hexagonal IZO nanorods exhibited several sharp and well-defined diffractions peaks corresponding to the diffraction planes of (100), (002), (101), (102), (110), and (103) at diffraction angles of $31.79^{\circ}, 34.35^{\circ}$, $36.23^{\circ}, 47.79^{\circ}, 56.57^{\circ}$, and $62.81^{\circ}$, respectively. However, the IZO nanodisks show several well-defined diffraction peaks appeared at $2 \theta=31.77^{\circ}, 34.45^{\circ}, 36.27^{\circ}, 47.79^{\circ}, 56.43^{\circ}$, and $62.79^{\circ}$, corresponding to the diffraction planes of (100), (002), (101), (102), (110), and (103), respectively. All of the observed diffraction peaks are well matched with the characteristic peaks of wurtzite hexagonal phase of $\mathrm{ZnO}$. The observed diffraction peaks are well-matched with the JCPDS data card no. 36-1451 and the reported literature [18,45-47]. The incorporation of the $\mathrm{In}^{3+}$ ions into the crystal lattice of the $\mathrm{ZnO}$ can be confirmed by the presence of additional peaks for $\operatorname{In}_{2} \mathrm{O}_{3}$ corresponding to diffraction planes (220), (222), (411), and (332) [48-50]. However, the peak for diffraction planes (220) was of very low intensity in case of IZO nanorods, which may be due to the very low concentration of the $\mathrm{In}^{3+}$ ions.

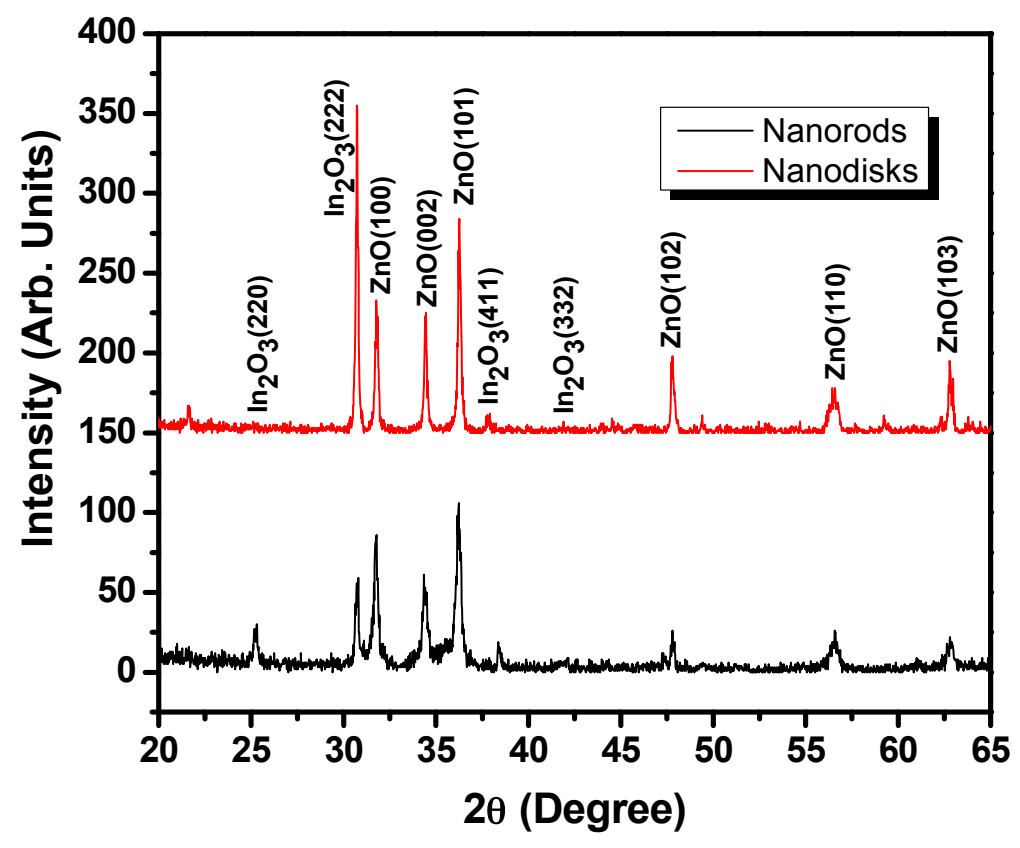

Figure 1. X-ray diffraction (XRD) diffraction patterns for In-doped $\mathrm{ZnO}(\mathrm{IZO})$ nanorods and nanodisks.

The crystallite sizes (d) of the thermally deposited IZO nanostructures were evaluated by using Debye-Scherrer equation (Equation (1)) [18,47].

$$
\mathrm{d}=\frac{0.89 \lambda}{\beta \cdot \operatorname{Cos} \theta}
$$

where, $\lambda=$ the wavelength of $\mathrm{X}$-rays used ( $\mathrm{Cu}-\mathrm{K} \alpha$ radiation with $\lambda=1.54 \AA$ ), $\theta$ is the Bragg diffraction angle and $\beta$ is the peak width at half maximum (FWHM). Three most intense peaks were considered for the calculation of FWHM, and thus the crystallite sizes of the IZO nanorods and nanodisks and the corresponding results are represented in Table 1. The average crystallite sizes of $24.80 \mathrm{~nm}$ and $42.24 \mathrm{~nm}$ were calculated for the In-doped $\mathrm{ZnO}$ nanorods and nanodisks, respectively. 
Table 1. The peak width at half maximum (FWHM) values and crystallite sizes of IZO nanostructures.

\begin{tabular}{|c|c|c|c|c|c|c|c|}
\hline \multirow{2}{*}{ S.N. } & \multirow{2}{*}{ (hkl) } & \multicolumn{3}{|c|}{ IZO Nanorods } & \multicolumn{3}{|c|}{ IZO Nanodisks } \\
\hline & & $2 \theta\left({ }^{\circ}\right)$ & FWHM ( $\beta)$ & Crystallite Size (nm) & $2 \theta\left({ }^{\circ}\right)$ & FWHM ( $(\beta)$ & Crystallite Size (nm) \\
\hline 1. & (100) & 31.79 & 0.29564 & 27.65 & 31.77 & 0.19751 & 41.39 \\
\hline 2. & (002) & 34.35 & 0.35795 & 22.99 & 34.45 & 0.1810 & 45.48 \\
\hline 3. & (101) & 36.23 & 0.34833 & 23.75 & 36.27 & 0.20768 & 39.84 \\
\hline
\end{tabular}

The morphology of the IZO nanostructures thermally synthesized at $700{ }^{\circ} \mathrm{C}$ is shown in Figure $2 \mathrm{a}-\mathrm{d}$. Stepped hexagonal nanorod shaped morphologies with uniform shape and sizes but with orientations in different directions can be clearly seen from low (Figure 2c,d) as well high (Figure 2a,b) magnification FESEM images. Some of these nanorods seem to be originated from a common base resulting in an urchin shaped structures. The average length of the nanorods was $\sim 1.5 \mu \mathrm{m}$, however, the diameter was not uniform. Each IZO nanorod further showed a hexagonal cross-section with a thickness of $\sim 150 \mathrm{~nm}$ (Figure $2 \mathrm{~b}$ ). The elemental composition of the IZO nanorods, as examined by the EDS attached with FESEM is shown in Figure 2e. The IZO nanorods are made of Indium, Zinc, and oxygen only. No other peak corresponding to any elemental impurity, prove that thermally synthesized nanorods are of high purity.
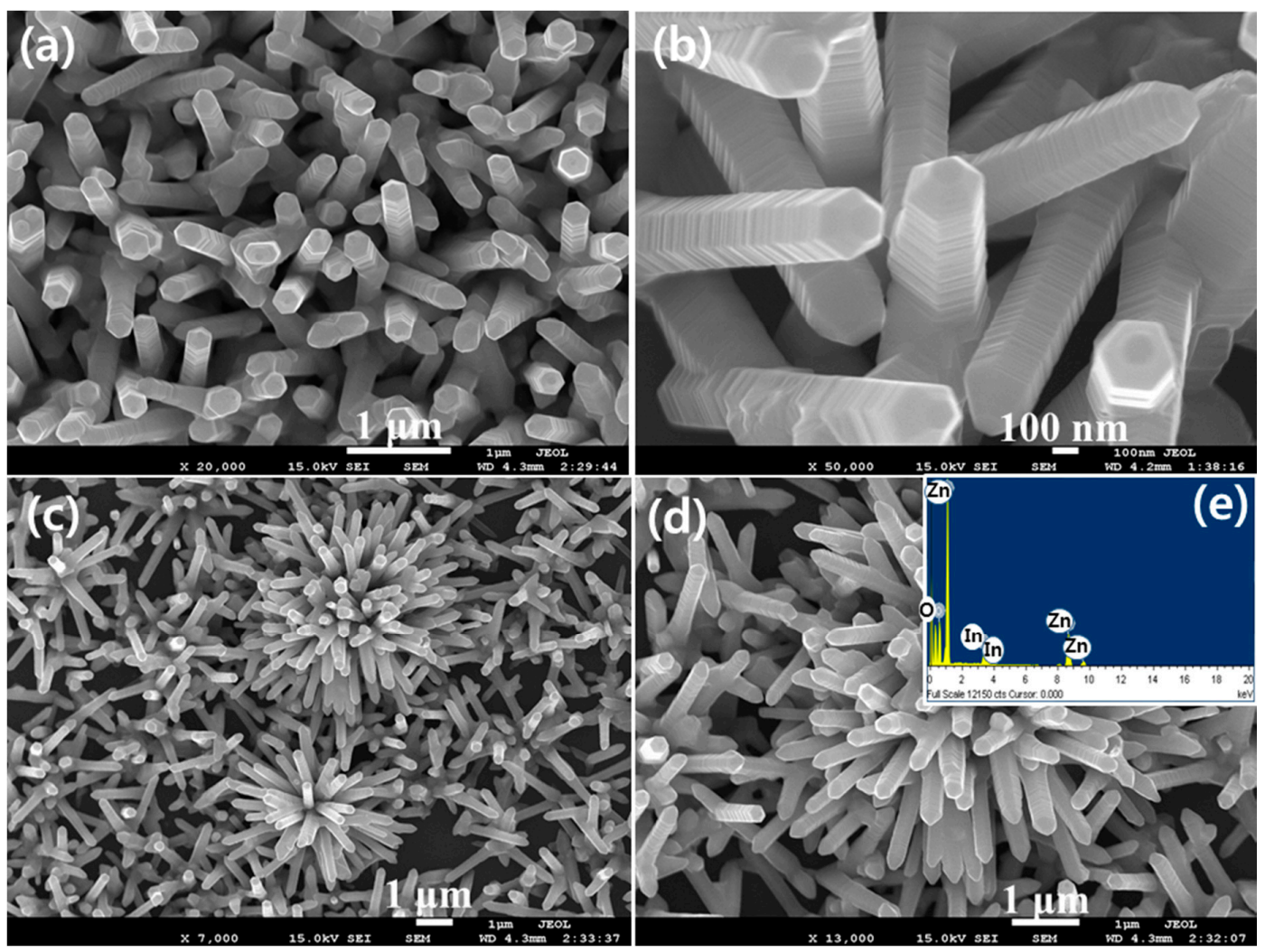

Figure 2. (a,b) High magnification (c,d) low magnification Field emission scanning electron microscopy (FESEM) images and (e) EDS spectrum of stepped hexagonal IZO nanorods synthesized at the $700{ }^{\circ} \mathrm{C}$ growth temperature.

The morphology of the IZO nanostructures thermally synthesized at $850{ }^{\circ} \mathrm{C}$ is shown in Figure 3a-c. Low magnification FESEM images shown in Figure 3a,b exhibit disk shaped morphologies. However, high magnification FESEM images, as shown in Figure 3c, revealed that the disk-shaped morphologies are further composed of hook-shaped structures that are interlocked with each other. The average diameter of disk shaped morphology was $\sim 250-300 \mathrm{~nm}$. Figure $3 \mathrm{~d}$ shows the EDS 
spectrum for the IZO nanodisks, which confirmed the purity of thermally deposited nanodisks as peaks for Indium, Zinc, and oxygen atoms are present.
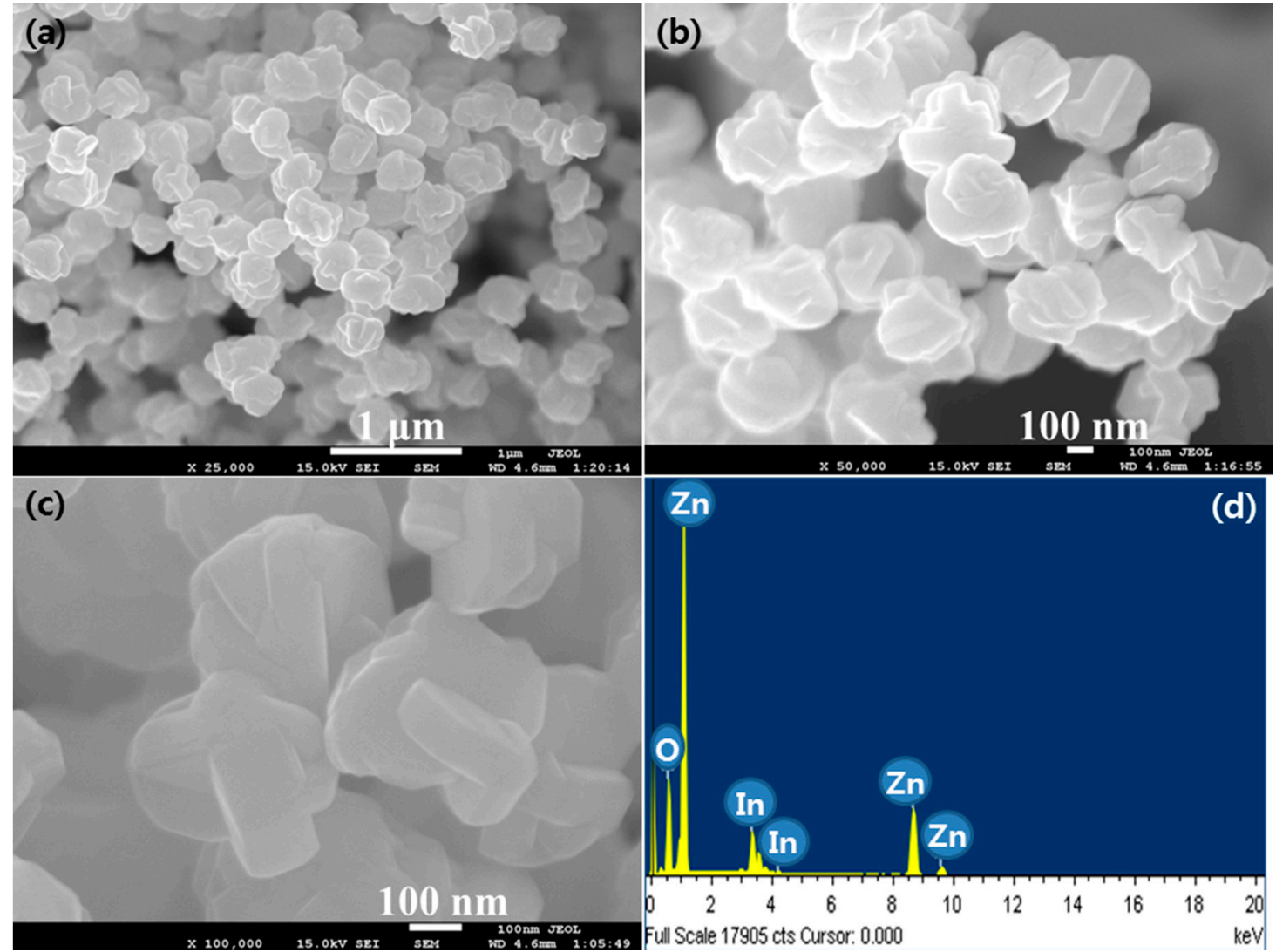

Figure 3. (a,b) Low magnification (c) high magnification FESEM images and (d) energy dispersive spectroscopy (EDS) spectrum of IZO nanodisks synthesized at the $850{ }^{\circ} \mathrm{C}$ growth temperature.

In order to evaluate the structural and optical property of the thermally deposited In-doped $\mathrm{ZnO}$ nanostructures, Photoluminescence spectroscopic analysis was performed at room temperature using a He-Cd source having $325 \mathrm{~nm}$ excitation wavelength. The corresponding PL spectra are shown in Figure 4. Strong UV emission peaks centered at $381.6(3.249 \mathrm{eV})$ and $381.4 \mathrm{~nm}(3.251 \mathrm{eV})$ were observed for In-doped $\mathrm{ZnO}$ nanorods and nanodisks, respectively. These peaks may be attributed to the near band edge emission (NBE) resulting due to recombination of free excitons as well as to the transition from 1 longitudinal optical (LO)-phonon replica of two electron satellites (TES) lines of $\mathrm{ZnO}$ [51-54]. A slight shift in band edge peak with a significant increase in the UV emission intensity for IZO nanodisks as compared to nanorods may be attributed to the better crystallinity of former, which is also confirmed by the XRD analysis (Figure 1). Additionally, broad but strong

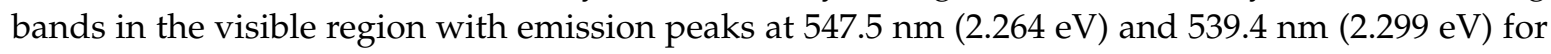
IZO nanorods and nanodisks, respectively, were also observed and can be assigned to is due to the superposition of green, yellow-orange, and red emissions $[51,55,56]$. The green emission bands for both the morphologies originate due to the radial recombination of a photogenerated positively charged hole $\left(\mathrm{h}^{+}\right)$with a negatively charged electron $\left(\mathrm{e}^{-}\right)$of the singly ionized oxygen $(\mathrm{O})$ vacancies on $\mathrm{ZnO}$ surface lattice $[57,58]$. 


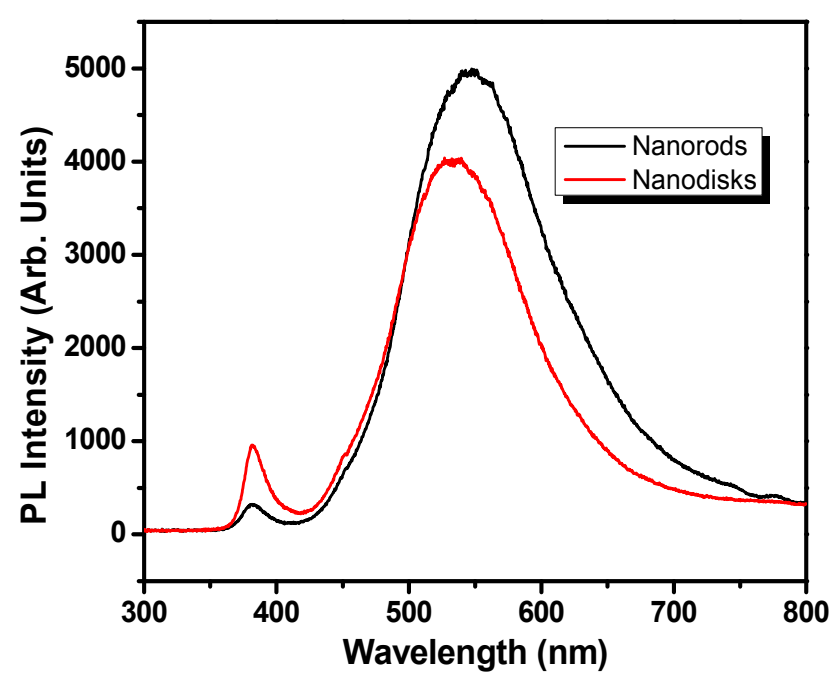

Figure 4. Typical room-temperature photoluminescence (PL) spectra of stepped hexagonal nanorods and flower-shaped IZO nanomaterials.

\subsection{Electrochemical Sensing Applications of IZO Nanostructures}

IZO nanostructures based electrochemical sensors were tested for the detection $0.05 \mu \mathrm{M}$ phenyl hydrazine in $0.1 \mathrm{M}$ phosphate buffer solution (PBS) with $\mathrm{pH}=7$, as compared to blank PBS.

The current responses were measured from 0.0 to $+1.5 \mathrm{~V}$. Significant increase in the current response for even very low concentration of $0.05 \mu \mathrm{M}$ phenyl hydrazine as compared to blank PBS confirms that both the doped $\mathrm{ZnO}$ nanostructures could act as efficient electron mediators and electro-catalysts for the electrochemical detection of phenyl hydrazine at room temperature (Figure 5a,b). For both of the sensors, a continuous increase in the current response was observed with an increase in the potential applied. At $+1.5 \mathrm{~V}$ current responses of $7.268 \mu \mathrm{M}$ and $6.903 \mu \mathrm{M}$ were recorded, respectively, for IZO nanorods and nanodisks based sensors.

For the estimation of important sensing parameters like sensitivity, linear dynamic range, detection limit, and correlation coefficient, a series electrochemical sensing experiments were conducted using both the IZO nanostructured modified electrodes using different concentrations. A series of phenyl hydrazine solutions with a concentration range of $0.5 \mu \mathrm{M}-5.0 \mathrm{M}$ in $0.1 \mathrm{M}$ PBS were prepared. Figure $6 \mathrm{a}, \mathrm{b}$ represent the I-V response curves for IZO nanorods and nanodisks modified GCE, respectively, against various concentrations of phenyl hydrazine in 0.1 M PBS. Expectedly, a continuous increase in current response is seen with the sequential increase in the phenyl hydrazine concentrations from $0.5 \mu \mathrm{M}$ to $5.0 \mathrm{M}$ in $0.1 \mathrm{M}$ PBS. This may be attributed to the generation of a large number of ions due to ionization of phenyl hydrazine into resulting in large ionic strength at higher concentrations $[45,59]$. Current responses of $33.56 \mu \mathrm{A}$ and $51.29 \mu \mathrm{A}$ were observed for $5.0 \mathrm{M}$ concentrations of phenyl hydrazine in $0.1 \mathrm{M}$ PBS at $+1.5 \mathrm{~V}$ using GCE modified with IZO nanorods and nanodisks, respectively. Thus, from these results, it can be concluded that IZO nanodisks modified GCE exhibits better sensing performances than stepped hexagonal IZO nanorods modified GCE. 

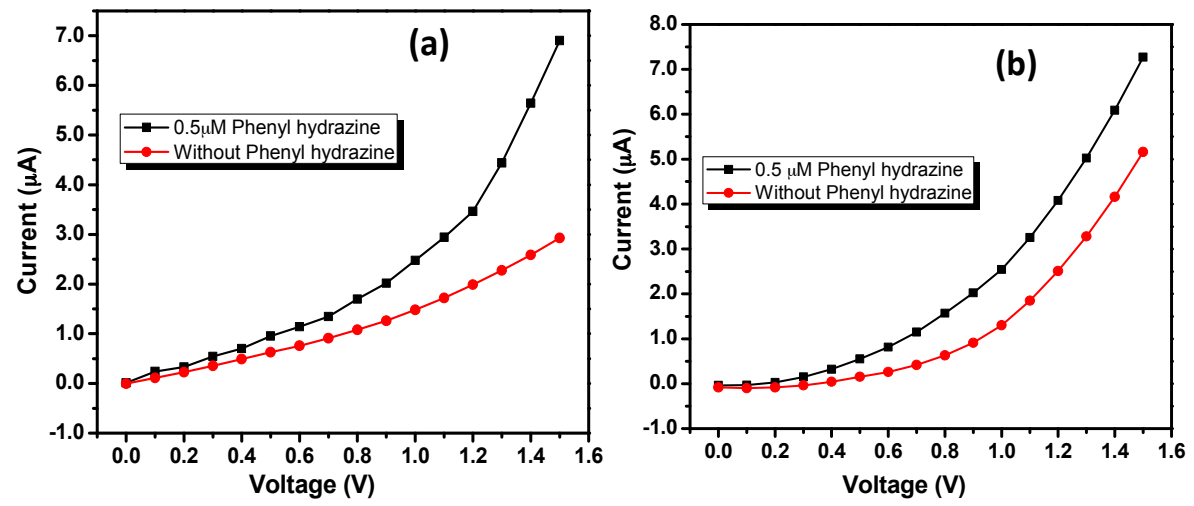

Figure 5. I-V response with $0.5 \mu \mathrm{M}$ phenyl hydrazine and without phenyl hydrazine using IZO (a) nanorods and (b) nanodisks modified GCE in 0.1 M PBS solution.
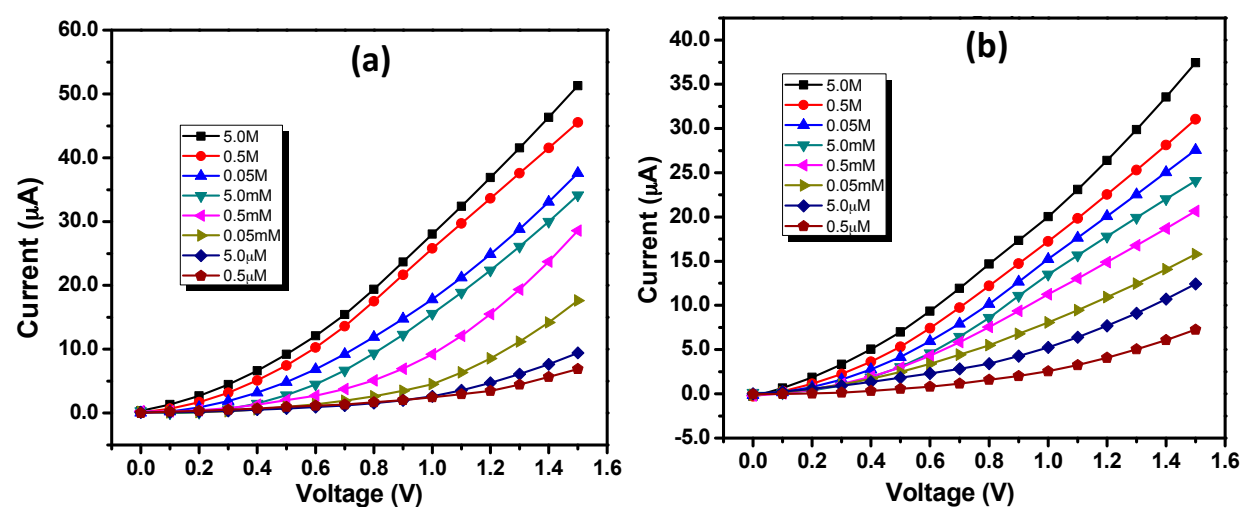

Figure 6. I-V responses for IZO (a) nanorods and (b) nanodisks against various concentrations of phenyl hydrazine $(0.5 \mu \mathrm{M}-5.0 \mathrm{M})$ in $0.1 \mathrm{M}$ phosphate buffer solution (PBS).

Figure 7 represents the respective calibration plots for IZO nanostructures. Sensitivity, linear dynamic range (LDR) and detection limits were evaluated from these calibration plots. Sensitivity was measured from the ratio of the slope of the calibration plot to the active surface area of the modified GCE $[18,45]$. For stepped hexagonal IZO nanorods modified GCE, sensitivity was $70.43 \mu \mathrm{A} \cdot \mathrm{mM}^{-1} \cdot \mathrm{cm}^{-2}$, whereas for IZO nanodisks modified GCE it was $130.18 \mu \mathrm{A} \cdot \mathrm{mM}^{-1} \cdot \mathrm{cm}^{-2}$. For both of the modified electrodes the LDR and experimental detection limits were $0.5 \mu \mathrm{M}-5.0 \mathrm{mM}$ and $0.5 \mu \mathrm{M}$, respectively. The high sensitivity of IZO nanodisks based sensors are due to the high surface to volume ratio of as-grown nanodisks when compared to the IZO nanorods. The low-dimensionality and reduced dimensions of the IZO nanodisks can be well-understood by the observed SEM images, as shown in Figures 2 and 3. Thus, it can be concluded that nanomaterials dimensions are significantly important for the sensing performance, and hence with reduced dimensions, enhanced sensitivity for the fabricated sensor based on IZO nanodisks can be achieved.

It has been reported that the greater the growth temperature the greater the density of defects on the surface of the nanomaterials due to the diffusion of the oxygen from the crystal lattices creating anion vacancies and enhancing the positive charge density [60-62]. As IZO nanodisks were grown at higher temperature i.e., $850{ }^{\circ} \mathrm{C}$ as compared to a $700{ }^{\circ} \mathrm{C}$ growth temperature for In-doped $\mathrm{ZnO}$ nanorods, the former exhibited superior sensing behavior.

The phenyl hydrazine responses for different sensors reported in the literature are summarized in Table 2. As grown IZO nanodisks based phenyl hydrazine sensor exhibited better sensitivities as compared to other reported sensors. Thus, IZO nanodisks could be efficient electron mediator and electro-catalyst for the fabrication of phenyl hydrazine chemical sensors. 
Table 2. Reported phenyl hydrazine sensing parameters of various nanostructures.

\begin{tabular}{|c|c|c|c|c|}
\hline Sensing Materials & $\begin{array}{c}\text { Sensitivity } \\
\left(\mu \mathrm{A} \cdot \mathrm{mM}^{-1} \cdot \mathrm{cm}^{-2}\right)\end{array}$ & $\begin{array}{c}\text { LDR } \\
(\mu \mathrm{M}-\mathrm{mM})\end{array}$ & $\begin{array}{c}\text { Detection limit } \\
(\mu \mathrm{M})\end{array}$ & Ref. \\
\hline $\mathrm{ZnO}$ nanourchin & 42.1 & $98.0-3.126$ & 78.6 & [45] \\
\hline $\mathrm{ZnO}-\mathrm{SiO}_{2}$ nanocomposite & 10.80 & $390.0-50.0$ & 1.42 & [63] \\
\hline $\mathrm{ZnO}-\mathrm{Fe}_{2} \mathrm{O}_{3}$ microwires & 8.33 & $10^{-3}-10.0$ & $6.7 \times 10^{-4}$ & [64] \\
\hline Al- doped ZnO Nanoparticles & 1.143 & $10.0-50.0$ & $1.215 \pm 0.02$ & [65] \\
\hline $\mathrm{CuO}$ hollow spheres & 0.578 & & & \\
\hline $\mathrm{CuO}$ flowers & 7.145 & $5 \times 10^{3}-10.0$ & $2.4 \times 10^{3}$ & [66] \\
\hline $\mathrm{Fe}_{2} \mathrm{O}_{3}$ nanoparticles & 57.88 & $97.0-1.56$ & 97 & [67] \\
\hline $\mathrm{Cd}_{0.5} \mathrm{Mg}_{0.5} \mathrm{Fe}_{2} \mathrm{O}_{4}$ ferrite nanoparticles & 7.01 & $3 \times 10^{3}-100$ & $3 \times 10^{3}$ & [68] \\
\hline $\mathrm{TiO}_{2}$ nanotubes & 40.9 & $0.25-0.10$ & 0.22 & [69] \\
\hline Ferrocene-modified carbon nanotube & 25.3 & $0.85-0.7$ & 0.6 & [70] \\
\hline IZO nanorods & 70.43 & $0.5-5.0$ & 0.5 & This study \\
\hline IZO nanodisks & 130.18 & $0.5-5.0$ & 0.3 & \\
\hline
\end{tabular}
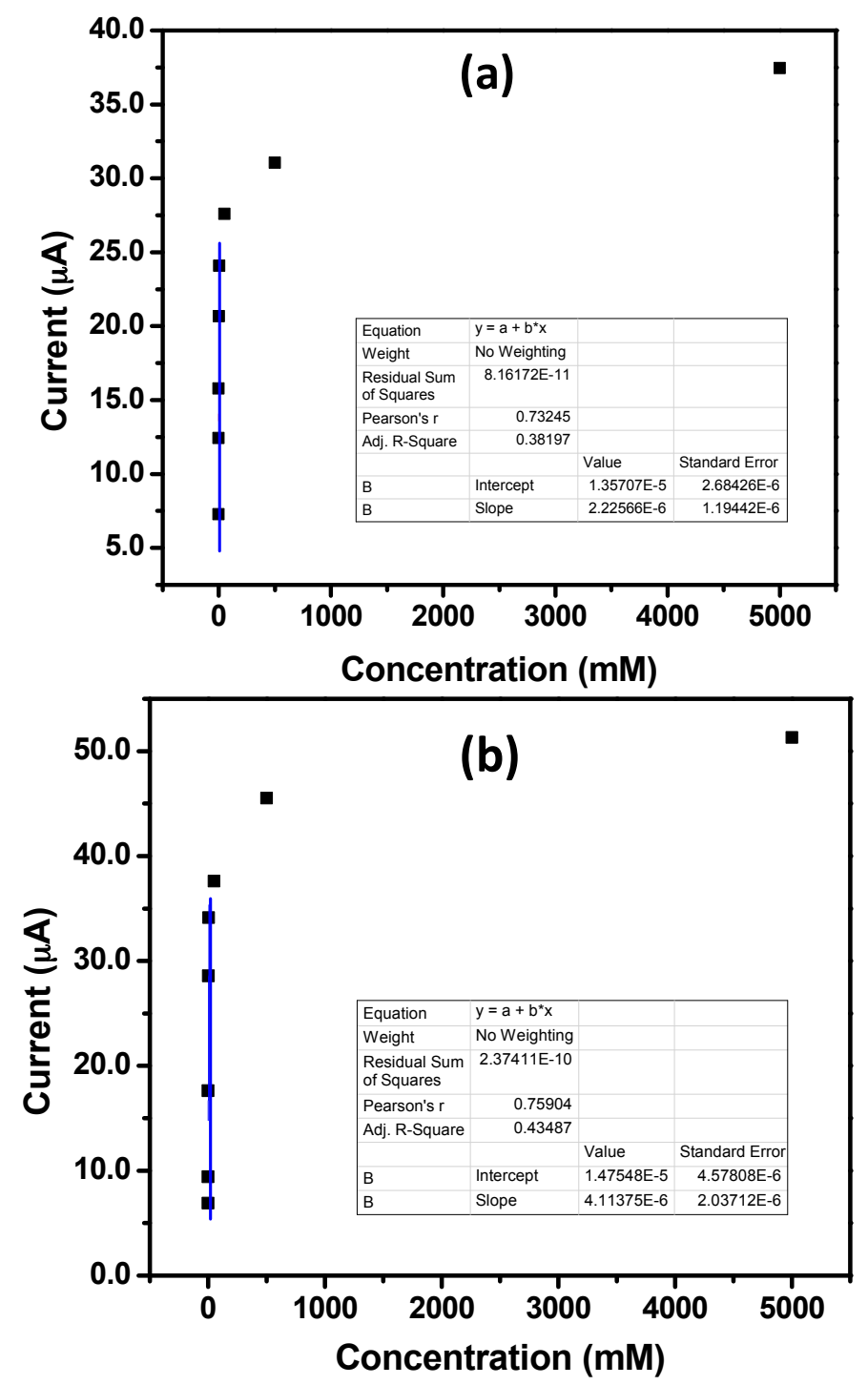

Figure 7. Calibration curves for IZO (a) nanorods and (b) nanodisks against various concentrations of phenyl hydrazine $(0.5 \mu \mathrm{M}-5.0 \mathrm{M})$ in $0.1 \mathrm{M}$ PBS. 


\subsection{Proposed Mechanism}

Doping of the $\mathrm{ZnO}$ nanostructures with $\mathrm{In}^{3+}$ ions induces the surface lattice defects along with an active surface area for the effective adsorption of the $\mathrm{O}_{2}$ molecules from the surrounding air, as well as the phenyl hydrazine molecules from the PBS [71,72]. The presence of electron donor $-\mathrm{NH}_{2}$ groups and $\pi$-electron density of the phenyl rings of phenyl hydrazine molecules further enhance the attractions between the analyte molecules and the active sites of the IZO nanostructures. The adsorbed $\mathrm{O}_{2}$ molecules are subsequently converted into oxygenated anionic species i.e., $\mathrm{O}_{2}{ }^{-}, \mathrm{O}^{2-}$, and $\mathrm{O}^{-}$etc. by extracting the conduction band electrons of the IZO nanostructures [73] (Equations (2)-(4)).

$$
\begin{gathered}
\mathrm{O}_{2(\mathrm{~g})}+\mathrm{e}^{-} \leftrightarrow \mathrm{O}_{2}^{-}(\mathrm{ads}) \\
\mathrm{O}_{2(\mathrm{~g})}+2 \mathrm{e}^{-} \leftrightarrow 2 \mathrm{O}_{(\mathrm{ads})}^{-} \\
\mathrm{O}_{2(\mathrm{~g})}+4 \mathrm{e}^{-} \leftrightarrow 2 \mathrm{O}_{(\mathrm{ads})}^{2-}
\end{gathered}
$$

These oxygenated chemical species oxidize the phenyl hydrazine molecules into diazenyl benzene (Figure 8). This oxidation process releases the electrons that are transferred back to the conduction band of the IZO nanostructures, thereby increasing the conductivity and hence the response current.

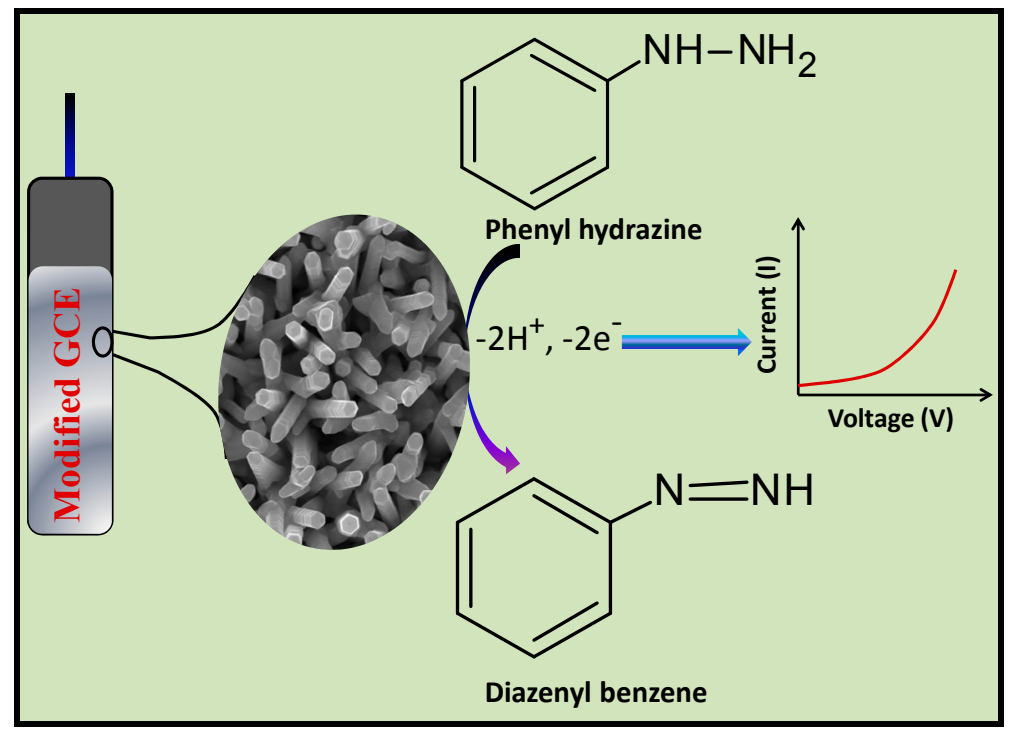

Figure 8. Proposed mechanism for phenyl hydrazine chemical sensing based on IZO nanostructures coated GCE by I-V technique.

\section{Conclusions}

In summary, In-doped $\mathrm{ZnO}$ (IZO) nanomaterials, i.e., stepped hexagonal nanorods and nanodisks were grown on silicon substrate by simple thermal evaporation process and characterized in detail using several techniques. The detailed morphological studies confirmed that both IZO nanomaterials possess well-crystallinity with wurtzite hexagonal phase and grown in high density. A suppressed UV emissions and strong green emissions for both IZO nanomaterials, i.e., nanorods and nanodisks were seen in the room-temperature PL spectra. The fabricated phenyl hydrazine chemical sensors based on as-grown IZO nanomaterials exhibited high sensitivities, i.e., $70.43 \mu \mathrm{A} \cdot \mathrm{mM}^{-1} \cdot \mathrm{cm}^{-2}$ and $130.18 \mu \mathrm{A} \cdot \mathrm{mM}^{-1} \cdot \mathrm{cm}^{-2}$, respectively, for nanorods and nanodisks. The experimental detection limits for both of the sensors were $0.5 \mu \mathrm{M}$, while the linear ranges were $0.5 \mu \mathrm{M}-5.0 \mathrm{mM}$.

Acknowledgments: The authors extend their appreciation to the Deanship of Scientific Research at King Khalid University for funding this work through research group program under grant number R.P.G.2/5/38. 
Author Contributions: Ahmad Umar, Sang Hoon Kim and Ahmed A. Ibrahim conceived and designed the experiments; Ahmad Umar, Sang Hoon Kim, Ahmed A. Ibrahim and Mohammad S. Al-Assiri performed the experiments; Ahmad Umar, Rajesh Kumar, Ahmed A. Ibrahim, A. E. Al-Salami and Sotirios Baskoutas analyzed the data; Ahmad Umar wrote the paper. All authors read, reviewed, revised and approved the manuscript.

Conflicts of Interest: The authors declare no conflict of interest.

\section{References}

1. Ibrahim, A.A.; Dar, G.N.; Zaidi, S.A.; Umar, A.; Abaker, M.; Bouzid, H.; Baskoutas, S. Growth and properties of Ag-doped $\mathrm{ZnO}$ nanoflowers for highly sensitive phenyl hydrazine chemical sensor application. Talanta 2012, 93, 257-263. [CrossRef] [PubMed]

2. Gholamian, F.; Sheikh-Mohseni, M.A.; Naeimi, H. Simultaneous determination of phenylhydrazine and hydrazine by a nanostructured electrochemical sensor. Mater. Sci. Eng. C 2012, 32, 2344-2348. [CrossRef]

3. Kennedy, J.; Murmu, P.P.; Leveneur, J.; Markwitz, A.; Futter, J. Controlling preferred orientation and electrical conductivity of zinc oxide thin films by post growth annealing treatment. Appl. Surf. Sci. 2016, 367, 52-58. [CrossRef]

4. Murmu, P.P.; Kennedy, J.; Williams, G.V.M.; Ruck, B.J.; Granville, S.; Chong, S.V. Observation of magnetism, low resistivity, and magnetoresistance in the near-surface region of Gd implanted ZnO. Appl. Phys. Lett. 2012, 101. [CrossRef]

5. Kaviyarasu, K.; Geetha, N.; Kanimozhi, K.; Magdalane, C.M.; Sivaranjani, S.; Ayeshamariam, A.; Kennedy, J.; Maaza, M. In vitro cytotoxicity effect and antibacterial performance of human lung epithelial cells A549 activity of Zinc oxide doped $\mathrm{TiO}_{2}$ nanocrystals: Investigation of bio-medical application by chemical method. Mater. Sci. Eng. C 2017, 74, 325-333. [CrossRef] [PubMed]

6. Sathyaseelan, B.; Manikandan, E.; Sivakumar, K.; Kennedy, J.; Maaza, M. Enhanced visible photoluminescent and structural properties of ZnO/KIT-6 nanoporous materials for white light emitting diode (w-LED) application. J. Alloys Compd. 2015, 651, 479-482. [CrossRef]

7. Kennedy, J.; Fang, F.; Futter, J.; Leveneur, J.; Murmu, P.P.; Panin, G.N.; Kang, T.W.; Manikandan, E. Synthesis and enhanced field emission of zinc oxide incorporated carbon nanotubes. Diam. Relat. Mater. 2017, 71, 79-84. [CrossRef]

8. Kaviyarasu, K.; Magdalane, C.M.; Kanimozhi, K.; Kennedy, J.; Siddhardha, B.; Reddy, E.S.; Rotte, N.K.; Sharma, C.S.; Thema, F.T.; Letsholathebe, D.; et al. Elucidation of photocatalysis, photoluminescence and antibacterial studies of $\mathrm{ZnO}$ thin films by spin coating method. J. Photochem. Photobiol. B Biol. 2017, 173, 466-475. [CrossRef] [PubMed]

9. Kennedy, J.; Murmu, P.P.; Leveneur, J.; Williams, V.M.; Moody, R.L.; Maity, T.; Chong, S.V. Enhanced power factor and increased conductivity of aluminum doped zinc oxide thin films for thermoelectric applications. J. Nanosci. Nanotechnol. 2018, 18, 1384-1387. [CrossRef]

10. Thi, V.H.T.; Lee, B.K. Effective photocatalytic degradation of paracetamol using La-doped ZnO photocatalyst under visible light irradiation. Mater. Res. Bull. 2016, 96, 171-182. [CrossRef]

11. Alam, U.; Khan, A.; Raza, W.; Khan, A.; Bahnemann, D.; Muneer, M. Highly efficient Y and V co-doped $\mathrm{ZnO}$ photocatalyst with enhanced dye sensitized visible light photocatalytic activity. Catal. Today 2017, 284, 169-178. [CrossRef]

12. Xing, L.-L.; Wang, Q.; Xue, X.-Y. One-Step Synthesis of Pt-ZnO Nanoflowers and Their Enhanced Photocatalytic Activity. Sci. Adv. Mater. 2016, 8, 1275-1279. [CrossRef]

13. Hassan, M.M.; Khan, W.; Mishra, P.; Islam, S.S.; Naqvi, A.H. Enhancement in alcohol vapor sensitivity of $\mathrm{Cr}$ doped ZnO gas sensor. Mater. Res. Bull. 2017, 93, 391-400. [CrossRef]

14. Sankar Ganesh, R.; Durgadevi, E.; Navaneethan, M.; Patil, V.L.; Ponnusamy, S.; Muthamizhchelvan, C.; Kawasaki, S.; Patil, P.S.; Hayakawa, Y. Low temperature ammonia gas sensor based on Mn-doped ZnO nanoparticle decorated microspheres. J. Alloys Compd. 2017, 721, 182-190. [CrossRef]

15. Li, X.; Hu, Z.; Liu, J.; Li, D.; Zhang, X.; Chen, J.; Fang, J. Ga doped ZnO photonic crystals with enhanced photocatalytic activity and its reaction mechanism. Appl. Catal. B Environ. 2016, 195, 29-38. [CrossRef]

16. Movlarooy, T. Transition metals doped and encapsulated $\mathrm{ZnO}$ nanotubes: Good materials for the spintronic applications. J. Magn. Magn. Mater. 2017, 441, 139-148. [CrossRef] 
17. Ibrahim, A.A.; Tiwari, P.; Al-Assiri, M.S.; Al-Salami, A.E.; Umar, A.; Kumar, R.; Kim, S.H.; Ansari, Z.A.; Baskoutas, S. A Highly-Sensitive Picric Acid Chemical Sensor Based on ZnO Nanopeanuts. Materials 2017, 10, 795. [CrossRef] [PubMed]

18. Ibrahim, A.A.; Umar, A.; Kumar, R.; Kim, S.H.; Bumajdad, A.; Baskoutas, S. $\mathrm{Sm}_{2} \mathrm{O}_{3}$-doped ZnO beech fern hierarchical structures for nitroaniline chemical sensor. Ceram. Int. 2016, 42, 16505-16511. [CrossRef]

19. Ngai, K.S.; Tan, W.T.; Zainal, Z.; Zawawi, R.M.; Juan, J.C. Electrochemical Sensor Based on Single-Walled Carbon Nanotube/ZnO Photocatalyst Nanocomposite Modified Electrode for the Determination of Paracetamol. Sci. Adv. Mater. 2016, 8, 788-796. [CrossRef]

20. Sun, H.; Jen, S.U.; Chiang, H.P.; Chen, S.C.; Lin, M.H.; Chen, J.Y.; Wang, X. Investigation of optoelectronic performance in In, Ga co-doped $\mathrm{ZnO}$ thin films with various In and Ga levels. Thin Solid Films 2016, 641, 12-18. [CrossRef]

21. Zhong, W.; Li, Z.; Zhang, L.; Wang, G.; Liu, Y.; Chen, W. Dependence of Electronic and Optical Properties of Zinc Oxide on Hydrostatic Pressure. Sci. Adv. Mater. 2016, 8, 1112-1115. [CrossRef]

22. Parthiban, R.; Balamurugan, D.; Jeyaprakash, B.G. Spray deposited ZnO and Ga doped ZnO based DSSC with bromophenol blue dye as sensitizer: Efficiency analysis through DFT approach. Mater. Sci. Semicond. Process. 2015, 31, 471-477. [CrossRef]

23. Park, N.M.; Oh, M.; Na, Y.B.; Cheong, W.S.; Kim, H. Sputter deposition of Sn-doped ZnO/Ag/Sn-doped $\mathrm{ZnO}$ transparent contact layer for GaN LED applications. Mater. Lett. 2016, 180, 72-76. [CrossRef]

24. Kumar, M.; Jeong, H.; Lee, D. Sol-gel derived Hf- and Mg-doped high-performance ZnO thin film transistors. J. Alloys Compd. 2017, 720, 230-238. [CrossRef]

25. Wang, Y.; Khan, M.Y.; Lee, S.-K.; Park, Y.-K.; Hahn, Y.-B. Parametric Study of Nozzle-Jet Printing for Directly Drawn ZnO Field-Effect Transistors. Sci. Adv. Mater. 2016, 8, 148-155. [CrossRef]

26. Liau, L.C.K.; Huang, J.S. Energy-level variations of $\mathrm{Cu}$-doped $\mathrm{ZnO}$ fabricated through sol-gel processing. J. Alloys Compd. 2017, 702, 153-160. [CrossRef]

27. Bernardo, M.S.; Villanueva, P.G.; Jardiel, T.; Calatayud, D.G.; Peiteado, M.; Caballero, A.C. Ga-doped $\mathrm{ZnO}$ self-assembled nanostructures obtained by microwave-assisted hydrothermal synthesis: Effect on morphology and optical properties. J. Alloys Compd. 2017, 722, 920-927. [CrossRef]

28. Nebatti, A.; Pflitsch, C.; Atakan, B. Unusual application of aluminium-doped ZnO thin film developed by metalorganic chemical vapour deposition for surface temperature sensor. Thin Solid Films 2017, 636, 532-536. [CrossRef]

29. Srinatha, N.; Raghu, P.; Mahesh, H.M.; Angadi, B. Spin-coated Al-doped ZnO thin films for optical applications: Structural, micro-structural, optical and luminescence studies. J. Alloys Compd. 2017, 722, 888-895. [CrossRef]

30. Wang, Y.; Xu, M.; Li, J.; Ma, J.; Wang, X.; Wei, Z.; Chu, X.; Fang, X.; Jin, F. Sol-combustion synthesis of Al-doped ZnO transparent conductive film at low temperature. Surf. Coat. Technol. 2017, 330, 255-259. [CrossRef]

31. Bhati, V.S.; Ranwa, S.; Fanetti, M.; Valant, M.; Kumar, M. Efficient hydrogen sensor based on Ni-doped ZnO nanostructures by RF sputtering. Sens. Actuators B Chem. 2018, 255, 588-597. [CrossRef]

32. Shewale, P.S.; Lee, S.H.; Yu, Y.S. Pulse repetition rate dependent structural, surface morphological and optoelectronic properties of Ga-doped $\mathrm{ZnO}$ thin films grown by pulsed laser deposition. J. Alloys Compd. 2017, 725, 1106-1114. [CrossRef]

33. Heo, J.; Kwon, S.J.; Cho, E.S. Nd: YVO4 Laser Direct Patterning of Aluminum-Doped Zinc Oxide Films Sputtered Under Different Process Conditions. Sci. Adv. Mater. 2016, 8, 1783-1789. [CrossRef]

34. Kaidashev, E.M.; Lorenz, M.; Von Wenckstern, H.; Rahm, A.; Semmelhack, H.C.; Han, K.H.; Benndorf, G.; Bundesmann, C.; Hochmuth, H.; Grundmann, M. High electron mobility of epitaxial ZnO thin films on c-plane sapphire grown by multistep pulsed-laser deposition. Appl. Phys. Lett. 2003, 82, 3901-3903. [CrossRef]

35. Chava, R.K.; Kang, M. Improving the photovoltaic conversion efficiency of ZnO based dye sensitized solar cells by indium doping. J. Alloys Compd. 2017, 692, 67-76. [CrossRef]

36. Chung, C.; Kim, Y.J.; Han, H.H.; Lim, D.; Jung, W.S.; Choi, M.S.; Nam, H.-J.; Son, S.-K.; Sergeevich, A.S.; Park, J.-H.; et al. Synthesis of P-Type ZnO Thin Films with Arsenic Doping and Post Annealing. Sci. Adv. Mater. 2016, 8, 1857-1860. [CrossRef] 
37. Han, N.; Chai, L.; Wang, Q.; Tian, Y.; Deng, P.; Chen, Y. Evaluating the doping effect of Fe, Ti and Sn on gas sensing property of ZnO. Sens. Actuators B Chem. 2010, 147, 525-530. [CrossRef]

38. Park, J.C.; Kim, D.J.; Lee, H.-N. Characteristics of Amorphous Indium-Zinc-Oxide Thin-Film Transistors Fabricated with a Self-Aligned Coplanar Structure and an $\mathrm{NH}_{3}$ Plasma Contact Doping Process. Sci. Adv. Mater. 2016, 8, 295-300. [CrossRef]

39. Liau, C.K.; Huang, J.-S. Effect of indium- and gallium-doped $\mathrm{ZnO}$ fabricated through sol-gel processing on energy level variations. Mater. Res. Bull. 2018, 97, 6-12. [CrossRef]

40. Ghosh, S.; Saha, M.; De, S.K. Tunable surface plasmon resonance and enhanced electrical conductivity of In doped ZnO colloidal nanocrystals. Nanoscale 2014, 6, 7039-7051. [CrossRef] [PubMed]

41. Badadhe, S.S.; Mulla, I.S. $\mathrm{H}_{2} \mathrm{~S}$ gas sensitive indium-doped $\mathrm{ZnO}$ thin films: Preparation and characterization. Sens. Actuators B Chem. 2009, 143, 164-170. [CrossRef]

42. Dhahri, R.; Hjiri, M.; El Mir, L.; Alamri, H.; Bonavita, A.; Iannazzo, D.; Leonardi, S.G.; Neri, G. CO sensing characteristics of In-doped ZnO semiconductor nanoparticles. J. Sci. Adv. Mater. Devices 2017, 2, $34-40$. [CrossRef]

43. Wang, Z.; Tian, Z.; Han, D.; Gu, F. Highly Sensitive and Selective Ethanol Sensor Fabricated with In-Doped 3DOM ZnO. ACS Appl. Mater. Interfaces 2016, 8, 5466-5474. [CrossRef] [PubMed]

44. Ge, Y.; Wei, Z.; Li, Y.; Qu, J.; Zu, B.; Dou, X. Highly sensitive and rapid chemiresistive sensor towards trace nitro-explosive vapors based on oxygen vacancy-rich and defective crystallized In-doped $\mathrm{ZnO}$. Sens. Actuators B Chem. 2017, 244, 983-991. [CrossRef]

45. Umar, A.; Akhtar, M.S.; Al-Hajry, A.; Al-Assiri, M.S.; Dar, G.N.; Saif Islam, M. Enhanced photocatalytic degradation of harmful dye and phenyl hydrazine chemical sensing using $\mathrm{ZnO}$ nanourchins. Chem. Eng. J. 2015, 262, 588-596. [CrossRef]

46. Kumar, R.; Kumar, G.; Umar, A. ZnO nano-mushrooms for photocatalytic degradation of methyl orange. Mater. Lett. 2013, 97, 100-103. [CrossRef]

47. Al-Hadeethi, Y.; Umar, A.; Al-Heniti, S.H.; Kumar, R.; Kim, S.H.; Zhang, X.; Raffah, B.M. 2D Sn-doped ZnO ultrathin nanosheet networks for enhanced acetone gas sensing application. Ceram. Int. 2017, 43, 2418-2423. [CrossRef]

48. Liu, X.; Jiang, L.; Jiang, X.; Tian, X.; Sun, X.; Wang, Y.; He, W.; Hou, P.; Deng, X.; Xu, X. Synthesis of Ce-doped $\mathrm{In}_{2} \mathrm{O}_{3}$ nanostructure for gas sensor applications. Appl. Surf. Sci. 2018, 428, 478-484. [CrossRef]

49. Anand, K.; Kaur, J.; Singh, R.C.; Thangaraj, R. Preparation and characterization of Ag-doped $\mathrm{In}_{2} \mathrm{O}_{3}$ nanoparticles gas sensor. Chem. Phys. Lett. 2017, 682, 140-146. [CrossRef]

50. Sun, J.; Wang, Q.; Wang, Q.; Zhang, D.-A.; Xing, L.-L.; Xue, X.-Y. High Capacity and Cyclability of $\mathrm{SnO}_{2}-\mathrm{In}_{2} \mathrm{O}_{3} /$ Graphene Nanocomposites as the Anode of Lithium-Ion Battery. Sci. Adv. Mater. 2016, 8, 1280-1285. [CrossRef]

51. Kennedy, J.; Murmu, P.P.; Manikandan, E.; Lee, S.Y. Investigation of structural and photoluminescence properties of gas and metal ions doped zinc oxide single crystals. J. Alloys Compd. 2014, 616, 614-617. [CrossRef]

52. Mannam, R.; Kumar, E.S.; Priyadarshini, D.M.; Bellarmine, F.; DasGupta, N.; Ramachandra Rao, M.S. Enhanced photoluminescence and heterojunction characteristics of pulsed laser deposited $\mathrm{ZnO}$ nanostructures. Appl. Surf. Sci. 2017, 418, 335-339. [CrossRef]

53. Lv, Y.; Zhang, Z.; Yan, J.; Zhao, W.; Zhai, C.; Liu, J. Growth mechanism and photoluminescence property of hydrothermal oriented $\mathrm{ZnO}$ nanostructures evolving from nanorods to nanoplates. J. Alloys Compd. 2017, 718, 161-169. [CrossRef]

54. Jiang, X.; Shang, F.; Zhou, Z.; Wang, F.; Liu, C.; Gong, W.; Lv, J.; Zhang, M.; He, G.; Sun, Z. Temperature-Dependent Photoluminescence of ZnO Nanorods Grown by a Copper-Assisted Hydrothermal Method. Sci. Adv. Mater. 2015, 7, 1800-1803. [CrossRef]

55. Yi, X.Y.; Ma, C.Y.; Yuan, F.; Wang, N.; Qin, F.W.; Hu, B.C.; Zhang, Q.Y. Structural, morphological, photoluminescence and photocatalytic properties of Gd-doped ZnO films. Thin Solid Films 2017, 636, 339-345. [CrossRef]

56. Kennedy, J.; Carder, D.A.; Markwitz, A.; Reeves, R.J. Properties of nitrogen implanted and electron beam annealed bulk ZnO. J. Appl. Phys. 2010, 107, 103518. [CrossRef]

57. Kumar, A.S.; Huang, N.M.; Nagaraja, H.S. Influence of Sn doping on photoluminescence and photoelectrochemical properties of $\mathrm{ZnO}$ nanorod arrays. Electron. Mater. Lett. 2014, 10, 753-758. [CrossRef] 
58. Nishad, K.K.; Joseph, J.; Tiwari, N.; Kurchania, R.; Pandey, R.K. Investigation on Size Dependent Elemental Binding Energies and Structural Properties of ZnO Nanoparticles and Their Correlation with Observed Photo-Luminescence Behavior. Sci. Adv. Mater. 2015, 7, 1368-1378. [CrossRef]

59. Umar, A.; Akhtar, M.S.; Dar, G.N.; Baskoutas, S. Low-temperature synthesis of $\alpha-\mathrm{Fe}_{2} \mathrm{O}_{3}$ hexagonal nanoparticles for environmental remediation and smart sensor applications. Talanta 2013, 116, 1060-1066. [CrossRef] [PubMed]

60. Chen, C.-Y.; Liu, Y.-R.; Lin, S.-S.; Hsu, L.-J.; Tsai, S.-L. Role of Annealing Temperature on the Formation of Aligned Zinc Oxide Nanorod Arrays for Efficient Photocatalysts and Photodetectors. Sci. Adv. Mater. 2016, 8 , 2197-2203. [CrossRef]

61. Umar, A.; Kumar, R.; Kumar, G.; Algarni, H.; Kim, S.H. Effect of annealing temperature on the properties and photocatalytic efficiencies of $\mathrm{ZnO}$ nanoparticles. J. Alloys Compd. 2015, 648, 46-52. [CrossRef]

62. Ren, H.; Xiang, G.; Gu, G.; Zhang, X. Enhancement of ferromagnetism of ZnO:Co nanocrystals by post-annealing treatment: The role of oxygen interstitials and zinc vacancies. Mater. Lett. 2014, 122, 256-260. [CrossRef]

63. Ali, A.M.; Harraz, F.A.; Ismail, A.A.; Al-Sayari, S.A.; Algarni, H.; Al-Sehemi, A.G. Synthesis of amorphous ZnO-SiO2 nanocomposite with enhanced chemical sensing properties. Thin Solid Films 2016, 605, 277-282. [CrossRef]

64. Rahman, M.M.; Gruner, G.; Al-Ghamdi, M.S.; Daous, M.A.; Khan, S.B.; Asiri, A.M. Fabrication of highly sensitive phenyl hydrazine chemical sensor based on as-grown $\mathrm{ZnO}-\mathrm{Fe}_{2} \mathrm{O}_{3}$ microwires. Int. J. Electrochem. Sci. 2013, 8, 520-534.

65. Rahman, M.M.; Khan, S.B.; Jamal, A.; Faisal, M.; Asiri, A.M. Fabrication of phenyl-hydrazine chemical sensor based on Al-doped ZnO Nanoparticles. Sens. Transducers 2011, 134, 32-44.

66. Khan, S.B.; Faisal, M.; Rahman, M.M.; Abdel-Latif, I.A.; Ismail, A.A.; Akhtar, K.; Al-Hajry, A.; Asiri, A.M.; Alamry, K.A. Highly sensitive and stable phenyl hydrazine chemical sensors based on $\mathrm{CuO}$ flower shapes and hollow spheres. New J. Chem. 2013, 37, 1098-1104. [CrossRef]

67. Hwang, S.W.; Umar, A.; Dar, G.N.; Kim, S.H.; Badran, R.I. Synthesis and characterization of iron oxide nanoparticles for phenyl hydrazine sensor applications. Sens. Lett. 2014, 12, 97-101. [CrossRef]

68. Al-Heniti, S.H.; Umar, A.; Zaki, H.M.; Dar, G.N.; Al-Ghamdi, A.A.; Kim, S.H. Synthesis and Characterizations of Ferrite Nanomaterials for Phenyl Hydrazine Chemical Sensor Applications. J. Nanosci. Nanotechnol. 2014, 14, 3765-3770. [CrossRef] [PubMed]

69. Ameen, S.; Shaheer Akhtar, M.; Seo, H.K.; Shin, H.S. $\mathrm{TiO}_{2}$ nanotube arrays via electrochemical anodic oxidation: Prospective electrode for sensing phenyl hydrazine. Appl. Phys. Lett. 2013, 103. [CrossRef]

70. Afzali, D.; Karimi-Maleh, H.; Khalilzadeh, M.A. Sensitive and selective determination of phenylhydrazine in the presence of hydrazine at a ferrocene-modified carbon nanotube paste electrode. Environ. Chem. Lett. 2011, 9, 375-381. [CrossRef]

71. Xiang, D.; Lin, H.; Ma, J.; Chen, X.; Jiang, J.; Qu, F. A Facile Method for the Synthesis of Porous ZnO Hollow Microspheres and Their Gas Sensing Properties for Acetone. Sci. Adv. Mater. 2015, 7, 1319-1325. [CrossRef]

72. Khan, M.Y.; Ahmad, R.; Lee, G.H.; Suh, E.-K.; Hahn, Y.-B. Effect of Annealing Atmosphere on the Optical and Electrical Properties of Al-Doped ZnO Films and ZnO Nanorods Grown by Solution Process. Sci. Adv. Mater. 2016, 8, 1523-1529. [CrossRef]

73. Ibrahim, A.A.; Hwang, S.W.; Dar, G.N.; Kim, S.H.; Abaker, M.; Ansari, S.G. Synthesis and Characterization of Gd-Doped ZnO Nanopencils for Acetone Sensing Application. Sci. Adv. Mater. 2015, 7, 1241-1246. [CrossRef]

(C) 2017 by the authors. Licensee MDPI, Basel, Switzerland. This article is an open access article distributed under the terms and conditions of the Creative Commons Attribution (CC BY) license (http://creativecommons.org/licenses/by/4.0/). 